\title{
Mnohojazyčnost jako dílčí cíl výuky cizích jazyků a možnosti její podpory ${ }^{1}$
}

\author{
Miroslav Janík \\ Masarykova univerzita, Pedagogická fakulta, Institut výzkumu školního vzdělávání
}

Redakci zasláno 20. 2. 2014 / upravená verze obdržena 25. 6. 2014 /

k uveřejnění přijato 27. 6. 2014

\begin{abstract}
Abstrakt: Studie je věnována otázce mnohojazyčnosti jako dílčímu cíli² jazykového vzdělávání. Záměrem autora je nabídnout čtenáři vhled do problematiky výuky dalších cizích jazyků ve škole v kontextu podpory mnohojazyčnosti. V první části textu vymezíme koncepci mnohojazyčnosti, kterou chápeme jako zastřešující teoretický rámec pro naše pojetí (tedy pojetí mnohojazyčnosti jako dílčího cíle výuky cizích jazyků). Protože mnohojazyčnost definujeme jako schopnost žáka ovládat alespoň tři jazyky, navrhneme v následující části, jak tyto jazyky označovat a řadit. V další části nahlédneme osvojování dalších (tedy druhých, třetích, čtvrtých...) cizích jazyků a jejich specifika. Ve čtvrté části se zaměříme na didaktické uchopení koncepce mnohojazyčnosti a na možnou implementaci podpory mnohojazyčnosti do výuky dalších cizích jazyků. V poslední části se zaměříme na učitele a na jeho kompetence, kterými by měl disponovat, aby mohl ve výuce cizích jazyků smysluplně podporovat mnohojazyčnost.
\end{abstract}

Klíčová slova: mnohojazyčnost, teorie osvojování dalších cizích jazyků, učení se cizím jazykům, výuka cizích jazyků, koncepce didaktiky podporující mnohojazyčnost, model učitelovy kompetence k podpoře mnohojazyčnosti

Mnohojazyčnost je téma v České republice relativně málo rozpracované, avšak v kontextu současných trendů vzdělávací politiky poměrně naléhavé. V textu se pokusíme objasnit, proč považujeme tuto problematiku za důležitou a jaké přináší možnosti pro výuku cizích jazyků. Zejména v evropském kontextu jazykového vzdělávání se stává mnohojazyčnost velmi diskutovaným a politicky podporovaným tématem. V mnohých dokumentech Evropské unie se setkáváme s požadavkem, aby každý Evropan hovořil alespoň dvěma

1 Studie vznikla v rámci řešení projektu GA ČR P407/12/0432 Strategie učení se cizímu jazyku a výsledky vzdělávání: Analýza shluků a sekvencí strategií.

2 Vycházíme z obecně přijímaného názoru ukotveného i v RVP ZV, že cílem výuky cizích jazyků je komunikační kompetence žáků a mnohojazyčnost chápeme jako jeden z dílčích cílů, který by měl přispět k rozvoji komunikační kompetence.

DOI: $10.5817 /$ PedOr2014-3-330 
cizími jazyky (např. Rada Evropské unie, 2008). Také v České republice je od roku 2013 (RVP ZV, 2013, s. 27), stejně jako v naprosté většině evropských států, podporována (či přímo nařízena) výuka minimálně dvou cizích jazyků již od primárního (nejpozději však od nižšího sekundárního) stupně vzdělávání. Požadavek na znalost minimálně dvou cizích jazyků se tedy zdá být velmi aktuálním tématem, a proto se pokusíme $\mathrm{v}$ našem textu nastínit, jak by podpora mnohojazyčnosti měla být ve výuce ztvárněna a jak by podpora mnohojazyčnosti mohla přispět k efektivnější výuce cizích jazyků.

Mnohojazyčnost obecně představuje koncepci, která se dotýká mnoha oblastí. Je zájmem vzdělávací politiky, dotýká se výukové, popř. školní reality, zahrnuje procesy osvojování cizích jazyků. Mnohojazyčnost lze také pojímat jako individuální či celospolečenský fenomén. Zde se zaměříme pouze na mnohojazyčnost v kontextu výuky cizích jazyků na základní škole, a protože by se Česká republika dala (prozatím ${ }^{3}$ ) označit jako monolingvní země (i jediným úředním jazykem je čeština), sekáváme se s mnohojazyčností nejčastěji ve školní výuce dalších cizích jazykủ. Těžiště tohoto textu proto spočívá v oborové didaktice.

$\mathrm{V}$ textu se nejprve pokusíme stručně představit koncepci mnohojazyčnosti, přičemž největší pozornost budeme věnovat jejímu pojetí v souvislosti s výukou cizích jazyků. Následně představíme naše terminologické pojetí, pokud jde o označování a řazení jazyků; ozřejmíme, co chápeme pod pojmy cizí jazyk, první cizí jazyk, druhý cizí jazyk, další cizí jazyk. Poté se budeme zabývat mnohojazyčností ve vztahu k teoriím osvojování dalších cizích jazykư a učení se cizím jazykům a v neposlední řadě poukážeme na možné př́stupy $\mathrm{k}$ výzkumu osvojování jazyků. $\mathrm{V}$ návaznosti na to se zaměříme na možnosti implementace koncepce mnohojazyčnosti do výuky cizích jazyků a na závěr představíme model učitelovy kompetence $\mathrm{k}$ podpoře mnohojazyčnosti ve výuce cizích jazyků.

\section{Koncepce mnohojazyčnosti}

Pro uvedení do problematiky nabízíme terminologické uchopení koncepce mnohojazyčnosti. Je třeba zmínit, že se v našem výkladu zaměříme na cha-

3 Ze zprávy o Vývoji počtu cizinců s povolením $k$ pobytu v ČR (ČSÚ, 2012) vyplývá, že počet cizinců v České republice roste. Zatímco v roce 2004 bylo na našem území 193480 cizinců s trvalým pobytem, $v$ roce 2011 jich bylo již 424380 . Pokud bude tento trend pokračovat, nebude již v budoucnu možné Českou republiku považovat za monolingvní. 
rakterizaci mnohojazyčnosti v kontextu výuky cizích jazyků, učení se cizím jazykům a osvojování cizích jazykư4. V odborné literatuře se setkáváme s pojmy monolingvismus (jednojazyčnost, angl. monolingualism), bilingvismus (dvojjazyčnost, angl. bilingualism) a mnohojazyčnost (multilingvismus, angl. multilingualism). Tyto pojmy však v odborné literatuře nejsou jednotně definovány, natož pak používány a interpretovány. Kempová (2009) definuje monolingvismus jako schopnost používat jeden jazyk v jeho různých variantách. Bilingvismus je definován jako schopnost ovládat dva jazyky a mnohojazyčnost (multilingvismus, angl. multiligualism, něm. Mehrsprachigkeit) je charakterizován jako schopnost komunikovat ve třech a více jazycích (srov. Kemp, 2009, s. 14-15). Při hlubším zkoumání pojmu mnohojazyčnost ale zjistíme, že zmíněná definice není dostatečně výstižná. Problematická se jeví např́íklad otázka, jaké jazyky či jazykové varianty mohou být zahrnuty do rámce mnohojazyčnosti: pouze národní jazyky, dialekty, varianty jazyka nebo i individuální varianty jazyka? Hufeisenová (2010) upozorňuje na fakt, že na tyto otázky nelze najít $\mathrm{v}$ odborné literatuře uspokojivé odpovědi (Hufeisen, 2010, s. 376).

Další terminologický problém se skrývá ve vymezení mnohojazyčnosti vůči bilingvismu. Ani zde totiž zjevně neexistuje v odborné literatuře shoda. Zatímco někteří autoři považují pojmy mnohojazyčnost a bilingvismus jako více či méně synonymní (např. Bausch, Königs, \& Krumm, 2004), jiní je striktně oddělují (např. Gibson, Hufeisen, \& Personne, 2008). Pokud bychom oba pojmy oddělovali, byl by bilingvismus chápán ve vztahu pouze ke dvěma jazykům a mnohojazyčnost by se vztahovala $\mathrm{k}$ třem a více jazykům. Jiný pohled nabízí autoři (jako např. Jessner, 2008a), kteří se přiklánějí k vnímání mnohojazyčnosti jako nadřazeného pojmu vůči bilingvismu.

Terminologické uchopení pojmu mnohojazyčnost se zdá být o to složitější, že je závislé nejen na lingvistických, ale také na sociokulturních, politických, historických aj. faktorech. V odborné literatuře tak nalezneme celou řadu rozšiřujících definic, které charakterizují mnohojazyčnost na základě různých perspektiv. Na obecné rovině lze mnohojazyčnost chápat jako fenomén spole-

4 V našem textu (stejně jako např. Ellis, 2008) nebudeme př́sně rozlišovat mezi teoriemi učení se cizím jazykům a teoriemi osvojování cizích jazyků (viz Krashen, 1982), distinktivní funkci obou teorií budeme zdůrazňovat pouze tam, kde bude nutné pregnantně vyjádřit rozdíl mezi nimi. Toto rozdělení se totiž pro potřeby našeho textu nejeví jako vhodné a opíráme se o argument Königse (2010), že výzkum mimovýukového osvojování nelze oddělit od výuky cizího jazyka a obráceně (Königs, 2010, s. 753-754). 
čenský a individuální. Zatímco pod pojmem společenská mnohojazyčnost lze rozumět jazykové bohatství společensko-politického seskupení, individuální mnohojazyčnost je chápána jako jazykové bohatství jedince (srov. Kemmeter, 1999, s. 53). Hufeisenová (2010) poukazuje na to, že zejména v evropském politickém diskursu můžeme nalézt mnohojazyčnost definovanou jako ryze společenský fenomén a pro individuální mnohojazyčnost je pak zaváděn termín plurilingvismus (Hufeisen, 2010, s. 378). V českém prostředí se plurilingvismus ve shodě s terminologií užívanou Radou Evropy a Evropskou komisí překládá jako vícejazyčnost a je používán zejména $\mathrm{v}$ diskursu vzdělávací politiky a administrativy (Sladkovská \& Šmídová, 2010). Ve vědeckých debatách ale toto diferencování nebývá respektováno, mnohem častěji se užívá pouze termín mnohojazyčnost a pro účely daného výzkumu bývá přesně vymezeno její zaměření (srov. Hufeisen, 2010, s. 378).

Zůstaneme-li na individuální rovině, je možné definovat mnohojazyčnost jako „ovládání více jazyků ve smyslu jejich dynamické použitelnosti v konkrétní komunikační situaci“ (Krumm, 2003, s. 36). Vycházíme zde z přístupu k mnohojazyčnosti jako dynamickému systému jazyků, který se snaží zahrnout všechny možné způsoby osvojování jazyka a učení se jazykům v různých kontextech a zároveň klade důraz na kvalitativní změny při učení se cizím jazykům ve vztahu $\mathrm{k}$ počtu a pořadí osvojovaných jazyků (Jessner, 2008b, s. 270). Mnohojazyčnost také nutně neznamená dokonalou a stabilní znalost dvou nebo více jazyků a zároveň neznamená ani ovládání několika jazyků na stejné úrovni. Je třeba zmínit, že úroveň ovládání jazyků v debatách o mnohojazyčnosti nevychází z úrovní definovaných Společným evropským referenčním rámcem (SERR, 2002), ale opírá se o konstrukty komunikační kompetence a kompetence jednat v jazyce. Tyto konstrukty popisují ovládání jazyka následujícím způsobem: jedinec se dokáže vypořádat s komunikační situací, umí v daném jazyce jednat tak, že zvládne úspěšně realizovat řečové akty a dokáže dostát komunikačních cílů (Hufeisen, 2010, s. 377).

Ze zmíněného je tedy patrné, že se vědecké komunitě nedaří koncepci mnohojazyčnosti jednoznačně terminologicky vymezit. Zmíněná nejednotnost $\mathrm{v}$ chápání mnohojazyčnosti může pramenit z různých teoretických přístupů k mnohojazyčnosti. V oblasti cizojazyčného vzdělávání se nejčastěji setkáváme s př́stupy oborově didaktickými (např. Hufeisen, 1994; Roll \& Schilling, 2012; viz kapitola 4), př́stupy zaměřenými na kurikulum (např. Hufeisen, 2011) a př́stupy vycházejícími z teorií osvojování cizích jazyků (viz kapitola 3). V odborné literatuře se v kontextu mnohojazyčnosti setkáváme i se so- 
ciolingvistickými př́stupy (např. Blommaert, Collins, \& Slembrouck, 2005), s přístupy kognitivních věd (např. Vingerhoets et al., 2003; Eviatar, 1997) a nalezneme i celou řadu etnografických přístupů (např. Sorensen, 1967). Jednotlivé přistupy se mohou vzájemně překrývat, což může do značné míry komplikovat interpretaci výzkumných zjištění a jejich vzájemné srovnávání. Proto je nutné při výzkumu, ale i při diskusi o mnohojazyčnosti jasně formulovat, z jakých přístupů vycházíme a jakou „formou“ mnohojazyčnosti se zabýváme (srov. Hufeisen, 2010, s. 377-388).

V našem textu, i s vědomím poměrně velké problematičnosti, zůstaneme u chápání mnohojazyčnosti jako schopnosti na různých úrovních ovládat tři a více jazyků. Budeme se pohybovat pouze na úrovni individuální mnohojazyčnosti v kontextu školní výuky cizích jazyků a za východisko pro mnohojazyčnost budeme považovat teorie osvojování dalších jazykư ${ }^{5}$ Takto navržený př́stup skrývá dva závažné problémy. Zaprvé se musíme zabývat tím, co je to jazyk, cizí jazyk či další cizí jazyk, a zadruhé si nemůžeme nepoložit otázku, jak se jazyky (popř. cizí a další cizí jazyky) osvojují a učí. V následujících kapitolách se pokusíme velmi stručně nastínit oba problémy s tím, že se zaměříme zejména na terminologii $\mathrm{v}$ obou oblastech, která se nám jeví jako relevantní ve vztahu k výuce cizích jazyků.

\section{Jak označovat jazyky?}

Protože jsme zmínili, že mnohojazyčnost chápeme jako schopnost ovládat alespoň tři jazyky, je potřebné vyložit, jak budeme v tomto textu chápat jazy$\mathrm{ky}^{6}$ a jak je budeme označovat, popř jak budeme osvojované či učené jazyky řadit. Nebudeme se zde opírat o psycholingvistické teorie či o poznatky kognitivních věd, ty sice nabízí závažné poznatky o jazycích, ale pro náš kontext (výuky cizích jazyků) považujeme za vhodnější chápat jazyky v extenzivnějším smyslu. Tím máme na mysli, že jazyk chápeme spíše ve vztahu k lingvistice (tj. k morfologii, syntaxi, lexikologii atd.) a k jeho sociálnímu užití spíše než jako mentální procesy.

5 Naše pojetí osvojování cizích jazyků a učení se cizím jazykům volně navazuje na kompetitivní model osvojování cizího jazyka (MacWhinney, 1997), který vysvětluje osvojování jazyků (a učení se cizím jazykům) v souvislosti užitím jazyka ve specifických situacích a do centra pozornosti staví význam a kontext.

6 Jazyk na tomto místě chápeme obecně ve smyslu langue (viz De Saussure, 1996). 
Jazyky se lze zabývat z různých úhlů pohledu, jsou zkoumány v rámci mnoha vědeckých disciplín, a proto se zdá, že obecně platná definice jazyků v odborné literatuře není k dispozici. V kontextu učení se cizímu jazyku nabízí například Cooková (2010, s. 7) šest možných ekvivalentních vnímání jazyka jako: (1) systém reprezentující člověka; (2) abstraktní externí entitu; (3) soubor aktuálních či potenciálních vět; (4) vlastnictví komunity; (5) znalost v mysli jedince a (5) formu jednání. Navíc už jen rozlišit variety či dialekty od jazyka je mnohdy takřka nemožné. Do centra pozornosti výzkumníků se tak dostávají spíše role, funkce a pozice jazyků a variet v určitém regionu či komunitě. Jazyky jsou dnes chápány spíše jako otevřené entity, které zohledňují jak geografický, tak společenský prostor (Gordon, 2005 in Kemp, 2009, s. 17). Přesně definovat jazyky jako takové ale není cílem našeho textu, proto se budeme držet intuitivního chápání jazyků, které odlišuje jazyky na základě lingvistických, sociálních a regionálních znaků a opírat se budeme o charakteristiku jazyků nastíněnou ve Společném evropském referenčním rámci, kde jsou jazyky uchopovány ve smyslu jich užití jako prostředku ke komunikaci (Rada Evropy, 2002, s. 9).

S ohledem na to, že jsme mnohojazyčnost definovali jako schopnost ovládat alespoň tři jazyky, měli bychom určit, jak tyto jazyky budeme označovat a jakje budeme řadit. V odborné literatuře se nejčastěji setkáváme s chronologickým řazením jazyků, tedy $\mathrm{v}$ časové posloupnosti tak, jak jsou osvojovány ${ }^{7}$. V zahraniční odborné literatuře se v kontextu výzkumu mnohojazyčnosti setkáváme s různým chápáním toho, co lze označit za mateřský jazyk (L1), první cizí jazyk (L2) popř. další cizí jazyk (L3). Pokusíme se tedy tyto pojmy na základě studia zahraniční literatury vymezit a následně navrhneme systematizaci, která by měla odpovídat českému úzu.

Jako L1 bývá v odborné komunitě označován mateřský jazyk, popř. první jazyk (L1). U monolingvních jedinců není s označením L1 jako mateřského jazyka problém. Komplikace s terminologií nastávají u bilingvních (popř. multilingvních) jedinců, protože zatímco někteří autoři se přiklánějí k názoru, že u těchto lidí lze hovořit o vícečetnosti prvního jazyka (např. Hufeisen \& Riemer, 2010), jiní označují jejich jazyky jako L1, L2 atd. (např. Grosjean, 2008). Jako L2 však bývají nejčastěji označovány ty jazyky, kterým se člověk učí (popř. si je osvojuje) více či méně záměrně.

7 Musíme ale zdůraznit, že námi představené označování a řazení jazyků neodkazuje na úroveň ovládání jednotlivých jazyků. 
$\mathrm{V}$ anglicky a německy mluvících zemích bývá zdůrazněn rozdíl mezi cizím jazykem (angl. foreign language, něm. Fremdsprache) a tzv. druhým jazykem (angl. second language, něm. Zweitsprache). Pojem cizí jazyk je používán tehdy, když cílový jazyk nefiguruje jako jazyk většinové společnosti, ve které se jedinec nachází. Druhý jazyk je pojem charakteristický pro učení se cizího jazyka v prostředí cílového jazyka. ${ }^{8}$

Pod zkratkou L3 (L4, ..., Lx) rozumíme druhý (třetí atd.) cizí jazyk. Mnohdy bývají jako L3 označovány všechny další cizí jazyky, které se jedinec učí po mateřském a prvním cizím jazyku. $\mathrm{V}$ kontextu anglicky mluvících zemí se nejčastěji setkáváme s pojmenováním třetí jazyk (third language), který označuje bud' pouze druhý cizí jazyk, ale mnohdy také všechny cizí jazyky, které se člověk učí po prvním cizím jazyku (u bilingvních jedinců by se $\mathrm{v}$ závislosti na zvoleném označování mohlo jednat i o první cizí jazyk). Také se můžeme setkat s pojmem další jazyk (additional language popř. third additional language), který de-facto znamená totéž, jen je zde zdůrazněna posloupnost při učení se cizímu jazyku (srov. De Angelis, 2007, s. 5-10). V německy mluvícím prostředí nalezneme označení druhý cizí jazyk (zweite Fremdsprache), ale můžeme narazit i na pojem terciární jazyk (Tertiärsprache). Pod pojmem terciární jazyk rozumíme nejen druhý cizí jazyk, ale také všechny další cizí jazyky, kterým se jedinec učí po prvním cizím jazyku. Je třeba ale dodat, že jako terciární jazyky jsou označovány ty jazyky, které se člověk učí postupně jeden za druhým, tedy v časové následnosti (Marx \& Hufeisen, 2010, s. 826).

V českém prostředí chápeme jako L1 nejčastěji mateřský jazyk, označení první jazyk se v odborné literatuře takřka nepoužívá. V souvislosti s L2 u nás rozdělení na druhý jazyk a cizí jazyk v současné době není obvyklé, pro oba př́ípady používáme pojem cizí jazyk9 . Terminologie o oblasti L3 se

8 Rozdíl ve vnímání terminologického pojetí mezi německy mluvícím a anglicky mluvícím prostředí lze spatřit v tom, že v německy mluvícím prostředí bývá cizí jazyk (Fremdsprache) chápán také jako zastřešující pojem pro druhý a cizí jazyk, zatímco v anglické odborné literatuře se spíše setkáváme s pojetím druhého jazyka jako zastřešujícího pojmu. Zweitsprache a foreign language jsou pak vnímány jako speciální př́ípady pro dané zastřešující pojmy (Hufeisen \& Riemer, 2010, s. 737-738).

9 Jako druhý jazyk bychom mohli v našem prostředí chápat češtinu jako cizí jazyk, s koncepcí češtiny jako druhého cizího jazyka jsme se v naší odborné literatuře nesetkali. Můžeme se též setkat s pojmem čeština pro cizince, který označuje aplikovaný obor - tedy výuku češtiny pro jinojazyčné mluvčí (Hrdlička, 2010, s. 10). Analogicky by se daly jako druhý jazyk nazývat např angličtina jako cizí jazyk, němčina jako cizí jazyk atd. 
zdá být v našem prostředí poměrně neukotvená a mnohdy nekompatibilní se zahraničím. Například Choděra (2006), ale také Hendrich (1988) používají ve svých pracích pojem druhý cizí jazyk, Repka a Gavora (1987) používají další světový jazyk, další cizí jazyk se pak objevuje v kurikulárních dokumentech (např. RVP ZV) a Andrášová (2011) pracuje s pojmem terciární jazyk. Pro ostatní jazyky se nejčastěji používá bud' numerické označení (např. pro L4 třetí cizí jazyk či čtvrtý jazyk) nebo se využívá souborného označení další cizí jazyky či terciární jazyky. Pro názornost jsme se pokusili uspořádat českou terminologii ${ }^{10} \mathrm{v}$ obrázku 1.

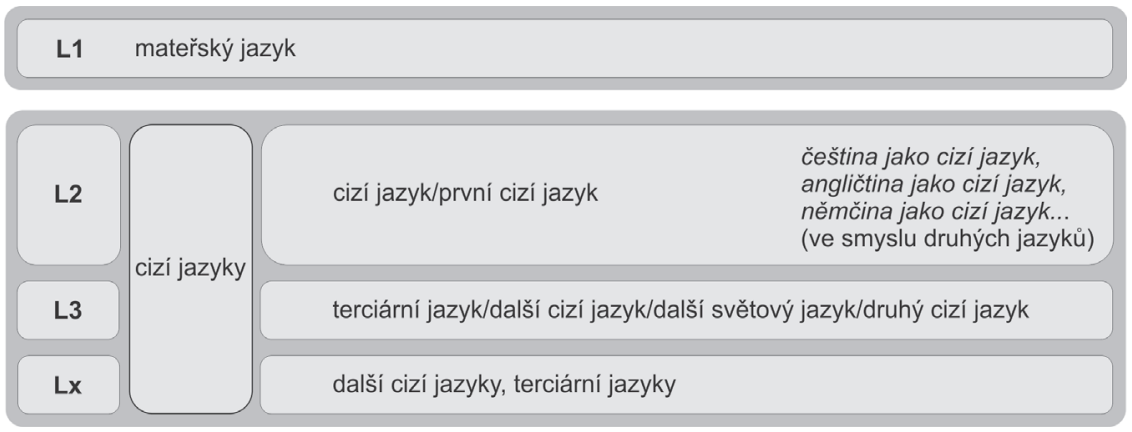

Obrázek 1. Návrh systematizace terminologie v oblasti označování a řazení jazyků.

Námi navržená systematizace terminologie vychází z „tradičních“ pojmenování. Jako L1 označujeme mateřský jazyk a L2 pak chápeme jako první cizí jazyk. Pod zkratkou L3 rozumíme (pouze) druhý cizí jazyk, protože pokud budeme chtít vyjádřit další (tedy třetí, čtvrté atd.) cizí jazyky, budeme využívat zkratku Lx. Stejně jako v německé i anglické terminologii zůstává rozlišení Lx (další cizí jazyky, popř. terciární jazyky) a L3 (terciární jazyk / další cizí jazyk / další světový jazyk / druhý cizí jazyk) poměrně nezřetelné. Nejen proto nelze tuto terminologii považovat za ideální. Navíc vychází z představy,

10 Terminologií v této oblasti se zabývala také Korčáková (2005), v níž označuje jazyky podle chronologického pořadí osvojování. Jejího označování jazyků se v tomto textu nebudeme držet. 
že naše země je monolingvní, a tak konstelace mateřský jazyk - cizí jazyky může fungovat jako princip pro označování jazyků. ${ }^{11}$

Protože náš text je prvořadě zaměřený na výukový kontext, považujeme za důležité zmínit, že z důvodu zjednodušení budeme v tomto textu mateřský jazyk žáků považovat za shodný s vyučovacím jazykem ve škole, první cizí jazyk žáka chápeme zároveň jako první cizí jazyk, který je vyučován ve škole, a žákův další cizí jazyk budeme vnímat jako shodný s dalším vyučovaným jazykem.

Jak jsme v této kapitole naznačili, není jednoduché najít terminologický konsenzus v označování jazyků tak, aby co nejlépe odpovídal vlastnímu jazykovému vybavení jedince. Ačkoli se přikláníme $\mathrm{k}$ „tradičnímu“ označování jazyků, uvědomujeme si jeho problematičnost. $V$ dalších kapitolách se budeme zabývat zejména druhým cizím jazykem a dalšími cizími jazyky a stručně nahlédneme, jak jsou tyto jazyky osvojovány. Teorie osvojování dalších cizích jazyků se nám totiž jeví jako podstatná součást koncepce mnohojazyčnosti ve vztahu k učení se cizím jazykům a výuce cizích jazyků.

\section{Teorie osvojování dalších cizích jazyků v kontextu mnohojazyčnosti}

V našem textu se dále zaměříme na teorie osvojování dalších cizích jazyků (a učení se cizím jazykům), protože hrají nepochybně významnou roli při rozvoji mnohojazyčnosti. $V$ českém prostředí představují tyto teorie relativně neprobádanou oblast, zabývá se jimi např́íklad Janíková (2014). V první řadě se ale pokusíme vyložit vztah teorií osvojování dalších cizích jazyků ke koncepci mnohojazyčnosti. Zatímco mnohojazyčnost budeme chápat jako určitý stav jazykové vybavenosti ${ }^{12}$ a osvojování dalších cizích jazyků vnímáme jako proces, který přispívá k rozvoji individuální mnohojazyčnosti. Vycházíme tedy z předpokladu, že individuální mnohojazyčnost je výsledkem procesů osvojování dalšího cizího jazyka a působení sociokulturních vlivů.

11 Zmíněné označování totiž může vést $\mathrm{k}$ paradoxům. Pokud se např́íklad vietnamská rodina s šestiletým dítětem přistěhuje do České republiky a dítě zde bude navštěvovat základní i střední školu, bude plně socializováno v českém prostředí a bude hovořit plynně česky, jeho mateřským jazykem zůstane dle tradiční terminologie vietnamština a paradoxně čeština, kterou hovoří už lépe než vietnamsky, zůstane pro něj cizí jazyk.

12 At' už budeme chápat mnohojazyčnost jako společenský či individuální cíl, nebo aktuální stav jedince či společnosti. 
Musíme však upozornit, že porozumění procesům osvojování L1, L2 a jejich vzájemným vztahům při osvojování není jasně vymezeno a s přidáním L3 je tato problematika ještě mnohem méně přehledná (srov. Jessner, 2008a, s. 18). V našem textu se budeme zaměřovat na specifikum osvojování dalších cizích jazyků - tedy na vztah mezi L2 a L3. ${ }^{13}$

Teorie osvojování dalších cizích jazyků (angl. third language acquisition) a koncepce mnohojazyčnosti jsou i v zahraničí poměrně nová témata, a tak využívají v současnosti výzkumné př́ístupy a terminologii „vypůjčenou“ z teorií osvojování cizího jazyka (angl. second language acquisition) a z oblasti výzkumu bilingvismu ${ }^{14}$ (De Angelis, 2007, s. 8). Teorii osvojování dalšího cizího jazyka však nelze považovat jen za rozšiřující koncepci osvojování prvního cizího jazyka či bilingvismu, ale je již nyní etablovanou samostatnou výzkumnou oblastí. Jejím zájmem jsou specifické procesy při osvojování dalších cizích jazyků a mohou být studovány relativně nezávisle na osvojování prvního cizího jazyka (srov. Rothman, Iverson, \& Judy, 2010, s. 6) či na poznatcích výzkumu bilingvismu (srov. Edwards \& Dewaele, 2007, s. 221-222).

De Angelis (2007) poukazuje na to, že v souvislosti s teorií osvojování dalších cizích jazyků se $v$ odborné literatuře setkáváme s celou řadou relativně nových koncepcí, které se sice vztahují k výzkumu této problematiky, ale každá z nich se zaměřuje na jiný aspekt. Zaprvé se setkáváme s koncepcí vícečetného osvojování jazyků (angl. multiple language acquisition), které zdůrazňuje osvojování více jazyků zároveň. Tím je míněno, že se nezabývá osvojováním jazyků, které probíhá postupně (tj. časově chronologicky). Předmětem jejího zájmu je např́íklad osvojování jazyků u dětí vyrůstajících v mnohojazyčném prostředí. Dále se můžeme setkat s pojmem mnohojazyčného osvojování (angl. multilingual acquisition). Toto označení na první pohled představuje jisté řešení vztahu mnohojazyčnosti a osvojování dalších jazyků. Mnohojazyčnost ale popisuje spíše stav, ve kterém je jedinec (či společnost) schopen komunikovat více jazyky. Osvojovat si mnohojazyčnost jako takovou tedy nelze - osvojovány mohou být pouze jazyky (i když se v mysli mohou při

13 Vztahem mezi L1 a L3 či teorií o interlanguage se zde nebudeme zabývat. Této problematice se věnoval např. Dewaele (1998).

14 Pro teorii osvojování dalších cizích jazyků je signifikantní zejména holististické pojetí, tedy že bilingvismus neznamená součet dvou více či méně ovládaných jazyků, ale spíše se jedná o specifickou jazykovou konfiguraci. Z tohoto pohledu by měl být bilingvismus koncipován jako komplexní celek, v jehož rámci nevnímáme kompetence v jazycích odděleně jeden od druhého, ale jako jeden komplexní systém (srov. Grosjean, 2008, s. 19-21). Další významné pojetí představuje dynamický bilingvismus (např. García, 2009). 
osvojování integrovat). Posledním pojmem vymezeným v této kapitole je osvojování dalších cizích jazyků (third angl. language acquisition, popř. third or additional language acquisition). Toto pojetí je asi nejméně problematické, protože neupřednostňuje jen jeden způsob osvojování cizího jazyka a zároveň terminologicky nejvíce odpovídá zkoumanému problému - tedy osvojování takových cizích jazyků, které se učíme po prvním cizím jazyce (srov. De Angelis, 2007, s. 10-11). V našem textu se proto držíme tohoto pojetí.

Osvojování dalších cizích jazyků v kontextu mnohojazyčnosti představuje také poměrně rozrůzněné výzkumné pole. $\mathrm{V}$ rámci teorií osvojování dalších cizích jazyků bývá nejčastěji zkoumán transfer mezi jazyky L2 a L3 (např. Heine, 2004; Göbel \& Vieluf, 2014), interference (např. Dentler, 1998), přepínání jazyků či jazykového kódu (např. Williams \& Hammarberg, 1998) a mezijazykové ovlivňování (např. Cenoz, 2003). Jessnerová (2008a) uvádí, že osvojování dalších cizích jazyků probíhá jak záměrně, tak nezáměrně, ale i v kombinaci obou (srov. Jessner, 2008a, s. 18). A nejen to. Komplexita teorií osvojování dalších cizích jazyků je zdůrazněna i různými psychosociálními a sociokulturními faktory, které ovlivňují osvojování cizích jazyků. V současné době se výzkum přiklání právě ke komplexnímu pojetí osvojování jazyků, které zahrnuje celou škálu vlivů. Pro potřeby našeho textu jsme vybrali následující přehled př́stupů k výzkumu osvojování cizích jazyků, ve kterých je pozornost zaměřena nejčastěji na:

- děti, které od narození vyrůstají v prostředí tř́ jazyků;

- bilingvní žáky, kteří se učí další cizí jazyk ve školním prostředí;

- bilingvní děti migrantů, které se učí další cizí jazyk v novém jazykovém prostředí;

- žáky, kteří sice vyrůstají v mnohojazyčném prostředí, mají ale jen jeden mateřský, jazyk a další cizí jazyky se učí simultánně ve školním prostředí;

- žáky, kteří se ve školním prostředí postupně učí první cizí jazyk a následně druhý cizí jazyk (srov. Jessner, 2008a, s. 19).

Tuto kategorizaci lze považovat spíše za zběžný přehled často zkoumaných oblastí než za úplný výčet všech výzkumných zaměření v oblasti osvojování dalších cizích jazyků. Dále je třeba zmínit, že v rámci teorií osvojování dalších cizích jazyků je vnímáno vlastní osvojování jako proces, který neprobíhá kontinuálně, bývá různě přerušován a $\mathrm{v}$ průběhu života případně restartován. Důsledkem nesouvislosti procesu osvojování je poměrně široké spektrum 
zájmu výzkumu, čímž se otevírá prostor pro různé přístupy, které se pokouší vysvětlit osvojování dalších cizích jazyků v jeho komplexnosti. V následující kapitole nahlédneme didaktický přístup podporující mnohojazyčnost, který vychází z posledně jmenovaného zaměření (tzn. zaměření na výuku ve školním prostředí, kde se žáci postupně učí první cizí jazyk a následně druhý cizí jazyk).

\section{$4 \quad$ Mnohojazyčnost jako dílčí cíl výuky dalších cizích jazyků}

V současné době existuje celá řada př́stupů $\mathrm{k}$ tomu, jak nahlížet mnohojazyčnost ve školní výuce. $V$ celosvětovém měřítku bývá nejčastěji zkoumána výuka a výukový kontext na školách, kde se používá více vyučovacích jazyků, popř. kde se jako vyučovací jazyk používá jiný jazyk než mateřský jazyk. V evropském prostoru bývají také zkoumány (minimálně) dva cizí jazyky, které jsou vyučovány jako školní předměty (Jessner, 2006, s. 120). Mnohojazyčnost ve výuce lze totiž chápat ve dvou rovinách. Zaprvé jde o výuku ve třídě, kde jsou přítomni mnohojazyční žáci (u nás např. Plischkeová, 2008). Zadruhé lze vnímat mnohojazyčnost jako jeden z možných cílů cizojazyčné výuky. Tyto dvě roviny se nevylučují, každá pouze akcentuje jiné aspekty. V našem textu se budeme zabývat výhradně mnohojazyčností v druhé rovině, tedy jako jeden z cílů cizojazyčné výuky.

Nahlédněme nyní na teoretické ukotvení mnohojazyčnosti v rámci didaktiky cizích jazyků. Koncepce didaktiky cizích jazyků podporující mnohojazyčnost (něm. Mehrsprachigkeitsdidaktik) vychází z komunikačního př́stupu k výuce cizích jazyků. Komunikační přístup totiž předpokládá, „že si jedinec na základě osobní jazykové socializace vytváří vlastní soubor komunikačních prostředků, který vzniká na základě individuální biografické konstelace a zkušeností" (Berthele, 2010, s. 226).

Pod vlivem teorií osvojování dalších cizích jazyků (popř. učení se cizím jazykům) klade koncepce didaktiky podporující mnohojazyčnost důraz na metalingvistickou a metakognitivní složku při učení se cizímu jazyku. Tím je míněno, že tato koncepce zdůrazňuje intencionální reflexi učených jazyků ve výuce, uvědomování si jejich rozdílů a podobností. Zároveň také podporuje reflexi procesů učení se cizím jazykům a tuto reflexi se snaží převést do výuky cizích jazyků. Jinými slovy, didaktika podporující mnohojazyčnost je založená na předpokladu, že ten, kdo se učí další cizí jazyk (L3), vlastní již soubor znalostí a zkušeností s učením se cizího jazyka (L2) a je schopen tyto 
znalosti a zkušenosti využít při učení se $\mathrm{L} 3^{15}$. Využití těchto zkušenosti může probíhat v mnoha rovinách, např́klad v rovině vyučování cizích jazyků, učení se cizím jazykům, kurikula a také v rovině výukových obsahů (např. výběr témat ve výuce, reálií atd.; srov. Pilypaitytė, 2011, s. 17). Dalším charakteristickým znakem koncepce didaktiky cizích jazyků podporující mnohojazyčnost je, že jednotlivé učené a naučené jazyky nemusí odpovídat a ani směřovat k úrovni rodilého mluvčího (učení se cizího jazyka se může orientovat pouze na jednu či více řečových dovedností nebo může být zacílena na vybranou tematickou oblast) a ani úroveň ovládání jazyků, jak již bylo výše zmíněno, nemusí být shodná (Neuner, 2003, s. 16).

Zatímco tradiční přístupy k výuce cizích jazyků měly tendenci jazyky od sebe striktně oddělovat, didaktické přístupy podporující mnohojazyčnost se spíše zaměřují na vytvoření rámce pro paralelní učení se několika cizím jazykům. Cílem výuky cizích jazyků $v$ kontextu mnohojazyčnosti by mělo být vytvoření takového jazykového profilu žáků, který umožní v jednotlivých jazycích reflektovat jejich komunikační, pragmatické, (inter)kulturní a další potřeby a naučit je, jak dále - $v$ prŕpadě potřeby - své jazykové znalosti, dovednosti, schopnosti atd. rozvíjet i po ukončení školní docházky. Druhým cílem by mělo být vytváření povědomí žáků o procesu osvojování cizích jazyků (tzv. procedurální znalosti). Právě tyto znalosti může žák využívat i po dokončení školní docházky, pokud se bude chtít učit dalším cizím jazykům či se v nich bude chtít jen zdokonalovat (srov. Neuner, 2003, s. 18-19). Přikláníme se tedy k názoru, že didaktika podporující mnohojazyčnost usiluje o vytvoření takového mentálního rámce, který umožní žákovi učení se cizím jazykům efektivněji, než kdyby se učil cizím jazykům aditivně.

Mnohojazyčnost jako jeden z cílů výuky cizích jazyků se potýká s mnohými otázkami, které do této doby nejsou uspokojivě zodpovězeny, jako například v jakém věku je optimální začít s učením se cizímu jazyku či jak a v jaké míre mohou být jazyky integrovány do společného kurikula (srov. Jessner, 2006, s. 122). Ve většině kurikulárních dokumentů u nás (ale i v zahraničí) jsou jednotlivé jazyky vnímány jako izolované jednotky a o možné integraci (či spíše „souhře“) cizích jazyků se kurikulární dokumenty nezmiňují (např. RVP ZV, 2013).

15 V kontextu didaktických př́stupů podporujících mnohojazyčnost můžeme v odborné literatuře nalézt přístupy didaktiky dalších cizích jazyků či tzv. terciární didaktiky (Andrášová, 2011), které zdůrazňují časovou posloupnost jazyků, které se jedinec učí. Naproti tomu př́istupy tzv. didaktiky intercomprehension (Bär, 2009) se zabývají učením se jazykům paralelně. V našem textu mezi učením se jazykům následně a paralelně rozlišovat nebudeme. 


\section{Model učitelovy kompetence $k$ podpoře mnohojazyčnosti ve výuce dalších cizích jazyků}

V předchozí kapitole jsme představili koncepci mnohojazyčnosti jako dílčí cíl cizojazyčné výuky a nyní se pokusíme ukázat, jakou kompetencí by měl učitel disponovat, aby mohla být mnohojazyčnost ve výuce dalších cizích jazyků podporována.

Diskuse o kompetencích učitele se v současné době zintenzivňují v souvislosti s požadavky na zkvalitnění výuky a s tím spojenými požadavky na profesionalizaci učitelského povolání. Na obecné rovině chápeme kompetence jako více či méně oborově specifické znalosti, dovednosti a strategie, které se lze naučit (Baumert et al., 2001, s. 22). Ve shodě s Píšovou et al. (2011, s. 54) zastáváme názor, že učitelství ve specifickém kontextu určitého oboru je nezaměnitelné s učitelstvím v kontextu oboru jiného. Např́klad Wipperfürthová (2009) charakterizuje klíčové kompetence učitele cizích jazyků a řadí mezi ně jazyk učitele, interkulturní kompetenci a právě mnohojazyčnost, které se budeme nadále věnovat.

Abychom mohli popsat kompetence, kterými by měl učitel disponovat, aby mohla být ve výuce dalších cizích jazyků podporována mnohojazyčnost, využili jsme model dle Hoppa et al. (2010). Původní Hoppův et al. (2010) model se teoreticky opírá o Shulmanovo (1986) pojetí pedagogických znalostí, podle kterého učitel disponuje znalostmi obsahu (angl. content knowledge), dále že má didaktické znalosti obsahu ${ }^{16}$ (angl. pedagogical content knowledge) a obecně pedagogické znalosti (angl. pedagogical knowledge). Posledně jmenované znalosti v modelu zohledněny nebyly. Dle Hoppa et al. (2010, s. 614), aby mohl učitel podporovat mnohojazyčnost ve výuce, jsou zapotřebí jeho znalosti (něm. Wissen), dovednosti (něm. Können) a ty se musí promítnout v jeho jednání (něm. Machen). A proto již zmíněné odborné znalosti, dovednosti a jednání tvoří základní složky jeho modelu. Pro Hoppův model je také podstatné, že se vztahuje na učitelovy kompetence $\mathrm{k}$ jazykové podpoře žáků prvního stupně a má za cíl představit možná kritéria pro vzdělávání a další vzdělávání učitelů v Německu. Jedná se tedy o model kompetencí k podpoře mnohojazyčnosti v mnohojazyčné třídě.

Námi upravený kompetenční model (tabulka 2) se zaměřuje na podporu mnohojazyčnosti jako (dílčího) cíle výuky dalších cizích jazyků, a tak i přes

${ }_{16}$ Koncept didaktických znalostí obsahu (pedagogical content knowledge) byl představen např́klad v Janík (2009). 
zachování složek znalostí, dovedností a jednání musely být jejich obsahy s ohledem na naše potřeby mírně přepracovány. Složka znalostí zahrnuje oblast znalosti struktur jazyků a funkce jazyků, zejména tedy dalšího cizího jazyka. Další oblast představuje znalosti procesů ve výuce cizích jazyků a procesů zaměřených na podporu mnohojazyčnosti, přičemž vycházíme zejména z teorií osvojování dalších cizích jazyků a z didaktických přístupů podporujících mnohojazyčnost. A v neposlední řadě je třeba zohlednit vývojově podmíněné procesy žáků (např. úroveň myšlení, kognitivní schopnosti atd.). Složka dovedností obsahuje výběr, využití a vyhodnocení diagnostických opatření, a také základní způsobilost k jazykové podpoře a jejích reflexí. Složka jednání zahrnuje přeměnu (transformaci) znalostí a dovedností v reálném čase a za daných okolností do výukových situací.

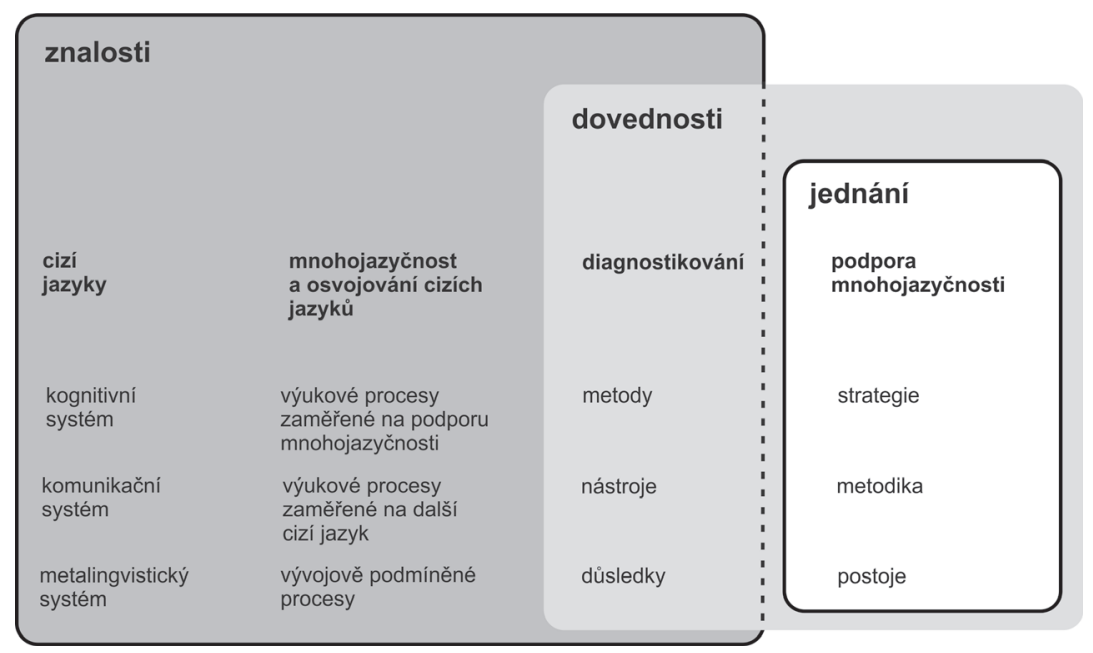

Obrázek 2. Model učitelovy kompetence k podpoře mnohojazyčnosti (upraveno dle Hopp et al., 2010).

Představený model (viz obr. 2) popisuje profesionální kompetence učitele dalších cizích jazyků, které jsou potřebné k podpoře mnohojazyčnosti ve výuce. V následující části textu popíšeme náš kompetenční model učitele a zaměříme se na jednotlivé oblasti (tzn. jazyky, mnohojazyčnost a osvojování cizích jazyků, diagnostikování a podporu mnohojazyčnosti). 


\subsection{Kompetenční oblast: Cizí jazyky}

Učitelova znalost vyučovaného cizího jazyka ( $\mathrm{v}$ našem př́ípadě dalšího cizího jazyka) je samozřejmým předpokladem úspěšné výuky cizího jazyka. V kontextu podpory mnohojazyčnosti se ale předpokládá učitelova znalost nejen dalšího cizího jazyka, ale i prvního cizího jazyka (popř. jiných dalších cizích jazyků), kterým se žáci učí (ačkoli nemusí být na stejné úrovni ovládání). Pokud bychom se chtěli držet Shulmanova (1986) pojetí pedagogických znalostí, mohli bychom chápat znalost cizích jazyků jako znalost obsahu.

Cizí jazyk zde můžeme rozdělit na znalosti o jazyce a využití jazyka při produkci a porozumění. Na úrovni znalostí lze cizí jazyky ${ }^{17}$ chápat ve třech dimenzích jako (1) formálně kognitivní systém, (2) komunikační systém a (3) metalingvistické povědomí o jazyce. První dimenze chápání jazyka obsahuje oblasti fonetiky a fonologie, morfosyntaxe, lexikální, sémantiky a pragmatiky. Ke znalostem o jazyce patří také druhá dimenze, tedy komunikační aspekty jazyka. Tím rozumíme např́íklad nespisovný jazyk, různé jazykové standardy, diskursivní funkce, komunikační strategie aj. Znalost jazyka na (3) metalingvistické úrovni by měla ve svém výsledku zdůraznit schopnost zaměřit se na lingvistickou formu jazyka, schopnost zaměřit se na formu a význam. Dle Jessnerové (2008b, s. 277) umožňuje metalingvistické povědomí o jazyce kategorizovat jazykové elementy, vnímat jejich funkci, formu, význam a porovnávat je. Pro koncepci mnohojazyčnosti je metalingvistické povědomí o jazyce velmi důležité.

\subsection{Kompetenční oblast: mnohojazyčnost a osvojování dalšího cizího jazyka}

Podpora mnohojazyčnosti může na úrovni znalostí vycházet ze znalosti o procesech osvojování cizích a dalších cizích jazyků, ze znalostí, jak se může projevovat jazykový transfer a mezijazykové ovlivňování, a ze znalosti teorií o didaktických př́stupech, podporujících mnohojazyčnost. $V$ souvislosti se Schulmanovým (1986) pojetím znalostí bychom tuto složku mohli chápat jako didaktickou znalost obsahu.

Jako výukové procesy zaměřené na podporu mnohojazyčnosti chápeme takový rozvoj žákovských cizojazyčných kompetencí, které umožní efektivnější učení se dalšímu cizímu jazyku na základě zkušenosti s procesem učení se

17 Jsme si vědomi toho, že kromě znalosti cizích jazyků může mít vliv na rozvoj mnohojazyčnosti i znalost mateřského jazyka (zejména na metalingvistické úrovni), ale touto problematikou se v našem textu nezabýváme. 
prvnímu cizímu jazyku. Podpora mnohojazyčnosti ve výuce cizích jazyků vychází ze znalostí didaktických přístupů podporujících mnohojazyčnost, znalostí teorií osvojování dalších cizích jazyků či jazykového transferu. Výukové procesy zaměřené na další cizí jazyk chápeme jako systematický rozvoj dalšího cizího (popř. druhého cizího) jazyka. Ačkoli totiž mluvíme o podpoře mnohojazyčnosti, nesmíme zapomenout, že stále zůstáváme na úrovni výuky jednoho konkrétního cizího jazyka. V neposlední řadě je třeba zmínit vývojově podmíněné procesy. Pod tímto pojmem rozumíme v našem kontextu zejména zohledňování kognitivního vývoje a věku žáků ve výuce. Zejména požadavky na záměrnou reflexi jazykủ či metakognitivní znalosti se jeví jako faktory, které vyžadují náročnější myšlenkové operace. V kontextu podpory mnohojazyčnosti by měl učitel při plánování a vlastní realizaci výuky věnovat zvýšenou pozornost kognitivnímu vývoji žáků a jejich věku.

\subsection{Kompetenční oblast: diagnostikování}

Pod pojmem diagnostikování míníme v kontextu mnohojazyčnosti jako cíle cizojazyčné výuky (1) identifikování situací nesoucích potenciál k podpoře mnohojazyčnosti, (2) rozpoznání vhodného opatření do výuky s ohledem na potřeby žáků, (3) vyhodnocení výsledků podpory mnohojazyčnosti. K tomu, aby bylo možné provést diagnostikování, je nutné znát základní postupy pozorování či testování, které se vztahují k výuce cizích jazyků (napřr záměrné a nezáměrné pozorování, dotazníkové šetření, standardizované testování aj.). Na základě takového diagnostikování je možné odvodit konkrétní závěry pro podporu mnohojazyčnosti ve výuce (srov. např. Schulz \& Tracy, 2010). Výsledky mohou být využity pro plánování výuky, ale také mohou poskytovat údaje o výsledcích takové výuky cizích jazyků, ve které je podporována mnohojazyčnost.

\subsection{Kompetenční oblast: podpora mnohojazyčnosti}

U učitele předpokládáme schopnost zacházet se situacemi, které nesou potenciál k podpoře mnohojazyčnosti. Tento předpoklad s sebou nese také požadavek na učitelovy strategie plánování a realizaci vlastní podpory mnohojazyčnosti, a tedy využití souboru vhodných metodických postupů. Jako strategie podpory mnohojazyčnosti v našem kontextu rozumíme systematické, transparentní a reflektivní jednání, které umožňuje intersubjektivně rozvíjet situace, které nesou potenciál k podpoře mnohojazyčnosti. Oblast metodiky pak pokrývá obsahovou dimenzi opatření k podpoře mnohojazyč- 
nosti. To znamená, že učitel je schopen podporovat mnohojazyčnost v běžné pedagogické praxi (viz např. Hufeisen, 1994). Z hlediska podpory mnohojazyčnosti ve výuce je třeba zmínit, že je potřebné ve výuce zohlednit nejen lingvistickou a metalingvistickou, ale také komunikační (tím rozumíme např́klad konverzační strategie v jazycích) či pragmatickou (jako napřs narativní kompetence) rovinu jazyka. V rámci podpory mnohojazyčnosti by měl být také zohledněn věk žáků a jejich kognitivní schopnosti a potřeby. Také vlastní monitoring je vhodný předpoklad pro reflektivní a kontextuálně vhodné využití metod podpory mnohojazyčnosti (Hopp et al., 2010, s. 621). Specifickou roli při podpoře mnohojazyčnosti hrají postoje žáků i učitelů. $V$ našem kontextu se jeví jako podstatné postoje k jazykům jako takovým, ale také $\mathrm{k}$ vlastní koncepci mnohojazyčnosti. Z mnohých výzkumů postojů učitelů totiž vyplývá, že ačkoli je mnohojazyčnost jako taková vnímána velmi pozitivně, reálné a přirozené mnohojazyčné jednání (např. používání slov z jiných jazyků) je učiteli vnímáno jako deficit při jazykové produkci (např. Grosjean, 2010, s. 105-106) a není chápána jako šance k podpoře komunikační kompetence ve škole (např. Gogolin, 1994, s. 206-207). Podpora mnohojazyčnosti je závislá na pozitivních postojích obou aktérů ve výuce stejně jako vnímání mnohojazyčnosti jako důležité složky ve výuce cizích jazyků (Hopp et al., 2010, s. 623).

\section{Shrnutí a diskuse}

Koncepce mnohojazyčnosti je v zahraničí velmi často diskutované téma, které postupně „prorůstá“ do odborných, ale i laických debat, zejména v kontextu vzdělávání v oblasti cizích jazyků a školního vzdělávání. V našich podmínkách považujeme za smysluplné zabývat se mnohojazyčností jako cílem výuky cizích jazyků. Z tohoto hlediska se nám jeví jako opěrný konstrukt teorie osvojování dalšího cizího jazyka a z ní vycházející koncepce didaktiky podporující mnohojazyčnost, která si klade za cíl efektivnější výuku dalších cizích jazyků na základě žákova využívání znalostí, zkušeností aj. z učení se prvnímu cizímu jazyku (popř. z výuky prvního cizího jazyka). Abychom ukázali, jak by mohla být mnohojazyčnost ve výuce cizích jazyků smysluplně podporována, vytvořili jsme kompetenční model učitele, který vychází z modelu Hoppa et al. (2010).

$V$ rámci závěrečné diskuse bychom kromě shrnutí rádi vznesli některé otázky týkající se mnohojazyčnosti ve výuce, které by měly přispět $\mathrm{k}$ debatám o možné podpoře mnohojazyčnosti ve výuce cizích jazyků. 
Jako první si klademe otázku, zda existuje elementární shoda všech aktérů ve vzdělávání na tom, že je potřebné, aby se žáci učili (alespoň) dva cizí jazyky. Ačkoli jsme zmínili, že Rada Evropské unie, ale už i RVP ZV (2013) se dvěma cizími jazyky na základní škole počítají, nezdá se nám, že by byly výhody žákovské znalosti minimálně dvou cizích jazyků v našem prostředí obecně uznávané (viz např. Münich, 2011). Pokud by totiž neexistoval obecný zájem o další cizí jazyky ve škole, můžeme považovat debatu o didaktických př́ístupech podporujících mnohojazyčnost ve výuce cizích jazyků za bezpředmětnou.

Zadruhé se ptáme, zda lze v České republice považovat mnohojazyčnost za dílčí cíl jazykové výuky. Ačkoli Evropská unie jednoznačně koncepci mnohojazyčnosti podporuje, u nás byla prosazena do RVP ZV (2013) „pouze“ povinnost základních škol nabízet dva cizí jazyky, ale o podpoře mnohojazyčnosti ve výuce cizích jazyků se zde nemluví (ačkoli na jiném místě RVP ZV je na deklaratorní úrovni zmíněna). Na druhé straně tato situace nabízí prostor pro výzkum v oblasti didaktiky cizích jazyků, aby nabídl hlubší poznání o výhodách (popř. rizicích) podpory mnohojazyčnosti ve výuce na českých školách.

Třetí otázka se týká učitelů dalších cizích jazyků, zda jsou připraveni ve své výuce podporovat mnohojazyčnost. Tato otázka sice není předmětem předloženého textu, chceme v ní ale upozornit na poměrně velký potenciál jak pro pedeutologicky orientovaný výzkum, tak pro instituce vzdělávající učitele cizích jazyků. Námi představený model učitelovy podpory mnohojazyčnosti by tak mohl přispět i k debatě o cílech a obsazích (kurikula) vzdělávání učitelů (dalších) cizích jazyků.

\section{Literatura}

Andrášová, H. (2011). Němčina jako další cizí jazyk po angličtině. In V. Janíková (Ed.), Výuka cizích jazyků (s. 134-156). Praha: Grada.

Andrášová, H. (2011). Tertiärsprachendidaktik und Mehrsprachigkeitsforschung - Anmerkungen zum Stand und zukünftigen Bedarf in Tschechien. In B. Sorger \& V. Janíková (Eds.), Mehrsprachigkeit in der Tschechischen Republik am Beispiel Deutsch nach Englisch (s. 29-38). Brno: Tribun.

Bär, M. (2009). Förderung von Mehrsprachigkeit und Lernkompetenz. Tübingen: Narr Francke Attempto Verlag.

Baumert, J., Stanat, P., \& Demmrich, A. (2001). PISA 2000: Untersuchungsgegenstand, Grundlagen und Durchführung der Studie. In Deutsches PISA-Konsortiom (Eds.), PISA 2000. Basiskompetenzen von Schülerinnen und Schülern im internationalen Vergleich (s. 15-68). Opladen: Leske + Budrich.

Bausch, K.-R., Königs, F. G., \& Krumm, H.-J. (2004). Mehrsprachigkeit im Fokus. Tübingen: Narr. 
Berthele, R. (2010). Mehrsprachigkeitskompetenz als dynamisches Repertoire - Vorüberlegungen zu einer integrierten Sprachdidaktik. In F. B. Bättig \& A. Tanner (Eds.), Sprachen lernen - Lernen durch Sprache (s. 225-239). Zürich: Seismo.

Blommaert, J., Collins, J., \& Slembrouck, S. (2005). Spaces of multilingualism. Language \& Communication, 25(3), 197-216.

Cenoz, J. (2003). Cross-linguistic influence in third language acquisition: Implications for the organization of the multilingual mental lexicon. Bulletin suisse de linguistique appliquée, 78, 1-11.

Cook, V. (2010). Prolegomena to second language learning. In P. Seedhouse, S. Walsh, \& Ch. Jenks (Eds.), Conceptualising "learning“ in applied linguistics (s. 6-22). Hampshire: Palgrave Macmillan.

Český statistický úřad (2012). Vývoj počtu cizinců s povolením k pobytu v ČR. Praha. Dostupné z http://www.czso.cz/csu/cizinci.nsf/kapitola/ciz_pocet_cizincu

De-Angelis, G. (2007). Third or additional language acquisition. Clevedon Hall: Multilingual Matters Ltd.

De Saussure, F. (1996). Kurs obecné lingvististiky. Praha: Academia.

Dentler, S. (1998). Systematizität und Prognostizierbarkeit lexikalischer Interferenzen. In S. Dentler, B. Hufeisen, B., \& Lindemann, Tertiärsprachen, Theorien, Modelle, Methoden (s. 31-47). Tübingen: Stauffenburg.

Dewaele, J.-M. (1998). French Interlanguage as L2 versus L3. Applied Linguistics, 19(4), 471-490.

Edwards, M., \& Dewaele, J.-M. (2007). Trilingual conversations: A window into multicompetence. International Journal of Bilingualism, 11(2), 221-242.

Ellis, R. (2008). The study of second language acquisition. Oxford: Oxford University Press.

Eviatar, Z. (1997). Language experience and right hemisphere tasks: The effects of scanning habits and multilingualism. Brain and Language, 58(1), 157-173.

García, O. (2009). Education, multilingualism and translanguaging in the 21st century. In A. Mohanty, M. Panda, R. Phillipson, \& T. Skutnabb-Kangas (Eds.), Multilingual education for social justice: Globalising the local (s. 128-145). New Delhi: Orient Blackswan.

Gibson, M., Hufeisen, B., \& Personne, C. (Eds.). (2008). Selected papers from the Freiburg conference on multilingualism and mupltiple language acquisition. Baltmannsweiler: Schneider Hohengehren.

Göbel, K., \& Vieluf, S. (2014). The effects of language transfer promoting instruction. In P. Grommes \& A. Hu (Eds.), Plurilingual education: Policies - practice - language development (s. 183-197). Amsterdam: John Benjamins.

Gogolin, I. (1994). Der monolinguale Habitus der multilingualen Schule. Münster: Waxman.

Grosjean, F. (2010). Bilingual: Life and reality. Cambridge: Harvard University Press.

Grosjean, F. (2008). Studying bilinguals. New York: Oxford University Press.

Heine, L. (2004). Mögliches und Unmögliches: Zur Erforschung von Transfererscheinungen. In B. Hufeisen \& N. Marx (Eds.), Beim Schwedischlernen sind Englisch und Deutsch ganz hilfreich (s. 81-95). Frankfurt: Peter Lang

Hendrich, J. (1988). Didaktika cizích jazyků. Praha: Státní pedagogické nakladatelství.

Hopp, H., Thoma, D., \& Tracy, R. (2010). Sprachförderkompetenz pädagogischer Fachkräfte. Zeitschrift für Erziehungswissenschaft, 13(4), 609-629.

Hrdlička, M. (2010). Kapitoly o češtině jako cizím jazyku. Plzeň: Fakulta pedagogická. 
Hufeisen, B. (2011). Gesamtsprachencurriculum: Weitere Überlugungen zu einem prototypischen Modell. In R. S. Baur, S. Rupprecht, \& B. Hufeisen (Eds.), „,Vieles ist ähnlich“, Individuelle und gesellschaftliche Mehrsprachigkeit als bildungspolitische Aufgabe (s. 256-282). Baltmannsweiler: Schneider Verlag Hohengehren.

Hufeisen, B. (2010). Bilingualität und Mehrsprachihkeit. In W. Hallet \& F. G. Königs (Eds.), Handbuch Fremdsprachendidaktik (s. 376-381). Seelze-Velber: Friedrich Verlag.

Hufeisen, B. (1994). Englisch im Unterricht Deutsch als Fremdsprache. München: Klett.

Hufeisen, B., \& Riemer, C. (2010). Spracherwerb und Sprachlernen: Modelle und theoretische Ansätze. In C. Fandrych, B. Hufeisen, H.-J. Krumm, \& C. Riemer (Eds.), Deutsch als Fremdund Zweitsprache (s. 737-752). Berlin: De Gruyter.

Choděra, R. (2006). Didaktika cizích jazyků. Brno: Academia.

Janík, T. (2009). Didaktické znalosti obsahu a jejich význam pro oborové didaktiky, tvorbu kurikula a učitelské vzdělávání. Brno: Paido.

Janíková, V. (2014). Individual multilingualism and its psycholinguistic aspects with regards to language learning. XLinguae, 7(1), 29-45.

Jessner, U. (2006). Linguistic awareness in multilinguals. Edinburgh: Edinburgh University Press Ltd.

Jessner, U. (2008a). Teaching third languages: Findings, trends and challenges. Language Teaching, 41(1), 15-56.

Jessner, U. (2008b). A DST model of multilingualism and the role of metalinguistic awareness. The Modern Language Journal, 92(2), 270-283.

Kemmeter, L. (1999). Multilingual gestütztes Vokabellernen im gymnasialen Englischunterricht. Frankfurt am Main: Peter Lang Verlag.

Kemp, Ch. (2009). Defining multilingualism. In L. Arionin \& B. Hufeisen (Eds.), The exploration of multilingualism (s. 11-26). Amsterdam: John Benjamins Publishing.

Korčáková, J. (2005). Chyba a učení cizím jazykům. Hradec Králové: Gaudeamus.

Königs, F. G. (2010). Zweitsprachenerwerb und Fremdsprachenlernen: Begriffe und Konzepte. In C. Fandrych, B. Hufeisen, H.-J. Krumm, \& C. Riemer (Eds.), Deutsch als Fremd- und Zweitsprache (s. 754-763). Berlin: De Gruyter.

Krashen, S. D. (1982). Principles and practice in second language acquisition. London: Longman.

Krumm, H.-J. (2003). Sprachenpolitik und Mehrsprachigkeit. In B. Hufeisen \& G. Neuner (Eds.), Mehrsprachigkeitskonzept - Tertiärsprachenlernen - Deutsch nach Englisch (s. 35-49). Strasbourg: Council of Europe.

MacWhinney, B. (1997). Second language acquisition and the competition model. In A. M. B. de Groot \& J. F. Kroll (Eds.), Tutorials in bilingualism: Psycholinguistic perspectives (s. 113-144). Mahwah: Lawrence Erlbaum Associates.

Marx, N., \& Hufeisen, B. (2010). Mehrsprachigkeitskonzepte. In C. Fandrych, B. Hufeisen, H.-J. Krumm, \& C. Riemer (Eds.), Deutsch als Fremd- und Zweitsprache (s. 826-832). Berlin: De Gruyter.

Neuner, G. (2003). Mehrsprachigkeitskonzept und Tertiärsprachendidaktik. In B. Hufeisen \& G. Neuner (Eds.), Mehrsprachigkeitskonzept - Tertiärsprachenlernen - Deutsch nach Englisch (s. 13-34). Strasbourg: Council of Europe.

Münich, D. et al. (2011). Závěrečná zpráva podskupin Národní ekonomické rady vlády pro konkurenceschopnost a podporu podnikání: Kapitola III - Vzdělanost. Praha. Dostupné z http:// www.vlada.cz/assets/media-centrum/aktualne/NERV_kap03.pdf 
Plischke, J. (2008). Výuka žáka s odlišným mateřským jazykem z hlediska př́pravy učitele. Olomouc: Univerzita Palackého v Olomouci.

Pilypaitytè, L. (2011). Mehr Sprachen lernen - sprachenpolitisch erwünscht, wissenschaftlich belegt, didaktisch erleichtert. In B. Sorger \& V. Janíková (Eds.), Mehrsprachigkeit in der Tschechischen Republik am Beispiel Deutsch nach Englisch (s. 12-20). Brno: Tribun EU.

Píšová, M., Najvar, P., Janík, T., Hanušová, S., Kostková, K., Janíková, V., Tůma, F. \& Zerzová, J. (2011). Teorie a výzkum expertnosti v učitelské profesi. Brno: Masarykova univerzita.

Rada Evropy. (2002). Společný evropský referenční rámec. Dostupné z http://www.msmt.cz/ mezinarodni-vztahy/spolecny-evropsky-referencni-ramec-pro-jazyky

Rada Evropské unie. (2008). Vzdělávání, mládež, kultura. Brusel. Dostupné z http://www. consilium.europa.eu/uedocs/cms_data/docs/pressdata/CS/educ/101414.pdf

Rámcový vzdělávací program pro základní vzdělávání. (2013). Praha. Dostupné z http://www. msmt.cz/vzdelavani/zakladni-skolstvi/upraveny-ramcovy-vzdelavaci-program-prozakladni-vzdelavani

Rothman, J., Iverson, M., \& Judy, T. (2010). Introduction: Some notes on the generative study of L3 acquisition. Second Language Research, 27(1), 5-19.

Repka, R., \& Gavora, P. (1987). Didaktika angličtiny. Bratislava: Slovenské pedagogické nakladatelstvo.

Shulman, L. (1986). Those who understand: Knowledge growth in teaching. Educational Researcher, 15(2), 4-14.

Roll, H., \& Schilling, A. (2012). Mehrsprachiges Handeln im Fokus von Linguistik und Didaktik. Duisburg: Universitätsverlag Rhein-Ruhr.

Schulz, P., \& Tracy, R. (2010). LiSe-DaZ. Linguistische Sprachstandserhebung - Deutsch als Zweitsprache. Göttingen: Hogrefe.

Sladkovská, K., \& Šmídová, T. (2010). Podpora vícejazyčnosti v Evropě. Dostupné z http://www. msmt.cz/vzdelavani/zakladni-vzdelavani/podpora-vicejazycnosti-v-evrope

Sorensen, A. P. (1967). Multilingualism in the Northwest Amazon. American Anthropologist, 69(6), 670-684.

Vingerhoets, G., Van Borsel, J., Tesink, C., van den Noort, M., Deblaere, K., Seurinck, R, ... \& Achten, E. (2003). Multilingualism: An fMRI study. NeuroImage, 20(4), 2181-2196.

Williams, S., \& Hammarberg, B. (1998). Language switches in L3 production: Implications for a polyglot speaking model. Applied Linguistics, 19(3), 295-333.

Wipperfürth, M. (2009). Welche Kompetenzstandarts brauchen profesionelle Fremdsprachenlehrer und -lehrerinnen? Forum Sprache, 1(2), 6-26.

\section{Autor}

Mgr. Miroslav Janík, Masarykova univerzita, Pedagogická fakulta, Institut výzkumu školního vzdělávání, Poříčí 31, Brno 602 00, e-mail: 183873@mail.muni.cz 


\section{Multilingualism as a particular goal of foreign language education and possibilities for its support}

Abstract: The study deals with the issue of multilingualism as a particular goal of language education. The author aims to offer an insight into the additional language teaching at primary/secondary schools in the context of multilingualism. The first part of the paper provides a definition of the concept of multilingualism, which forms the theoretical background of our study (i.e. multilingualism as a particular goal of language teaching). As we define multilingualism as pupils' ability to speak three or more languages, we propose a system for ordering and labelling these languages. The next part of the paper focuses on acquisition of additional (second, third etc.) languages and its characteristics. The fourth part of the paper deals with the didactic approach to the concept of multilingualism and its possible implementation into additional language teaching. Finally yet importantly, we focus on teachers and the competencies that they should have in order to meaningfully support multilingualism in instruction.

Keywords: multilingualism, theory of third or additional language acquisition, language teaching, didactic approach to support multilingualism, teacher's competence for multilingualism support

Petrová, Z. (Ed.). (2013). Prax v učitel'skom vzdelávaní: K otázkam praktickej prípravy učitelov $v$ študijnom programe Predškolská a elementárna pedagogi$k a$. Trnava: Typi Universitatis Tyrnaviensis.

Publikácia otvára klasický problém vztahu "teórie“ a „praxe“ vo vysokoškolskej príprave učitelov. Prezentuje pri tom cielene vytvorené videonahrávky výučbových aktivít, diskutované na fakultnom seminári, ako prostriedok umožňujúci študentom poznávat' otázky vzdelávacej praxe ako triedy problémov s akademickou relevanciou, ktoré môžu v praxi nadobúdat’ konkrétnu podobu v závislosti od špecifickej situácie výučby, nie ako rýdzo praktické problémy. Prostredníctvom vybraných vzdelávacích oblastí v bakalárskom študijnom programe Predškolská a elementárna pedagogika jednotlivé štúdie v publikácii ukazujú, ako je možné v rámci týchto oblastí venovat' vyvážený priestor klúčovým otázkam a témam akademického diskurzu v predmetnej oblasti, obsahovým a metodicko-didaktickým inováciám vychádzajúcim z nich a súčasne aj príprave študentov na realitu každodennej vzdelávacej praxe. Tento prístup má napomôct' tomu, aby bola vzdelávacia prax realizovaná študentom (budúcim učitel'om) nielen účinná, ale aj koncepčná, cielená a kriticky reflektovaná. 